\title{
CLEC12A wt Allele
}

National Cancer Institute

\section{Source}

National Cancer Institute. CLEC12A wt Allele. NCI Thesaurus. Code C162377.

Human CLEC12A wild-type allele is located in the vicinity of 12p13.31 and is approximately $48 \mathrm{~kb}$ in length. This allele, which encodes C-type lectin domain family 12 member A protein, plays a role in carbohydrate binding, cell signaling and the inhibition of myeloid cell functions. 